\title{
Interfaces
}

\section{An Túr Gloine (Tower of Glass) at the Newton Country Day School of the Sacred Heart}

\section{Virginia Raguin}

\section{(e) OpenEdition}

1 Journals

\section{Electronic version}

URL: http://journals.openedition.org/interfaces/310

DOI: 10.4000/interfaces.310

ISSN: 2647-6754

\section{Publisher:}

Université de Bourgogne, Université de Paris, College of the Holy Cross

\section{Printed version}

Date of publication: 1 January 2017

Number of pages: $39-64$

ISSN: $1164-6225$

\section{Electronic reference}

Virginia Raguin, "An Túr Gloine (Tower of Glass) at the Newton Country Day School of the Sacred

Heart", Interfaces [Online], 38 | 2017, Online since 13 June 2018, connection on 07 January 2021. URL: http://journals.openedition.org/interfaces/310 ; DOI: https://doi.org/10.4000/interfaces.310

Les contenus de la revue Interfaces sont mis à disposition selon les termes de la Licence Creative Commons Attribution 4.0 International. 


\title{
AN TÚR GLOINE (TOWER OF GLASS) AT THE NEWTON COUNTRY DAY SCHOOL OF THE SACRED HEART
}

\author{
Virginia Raguin
}

In 1925, the Religious of the Sacred Heart transferred their Boston school for girls to the former Tudor-Revival style estate of Loren D. Towle in Newton, Massachusetts [Fig.1]. The Boston architectural firm of Maginnis \& Walsh (founded in 1898 as Maginnis, Walsh, \& Sullivan) built the chapel and a four-story school wing between 1926 and 1928. Irish artists associated with the An Túr Gloine (Tower of Glass) Dublin collective produced the eight window program installed in 1929. The chapel's images present a compendium of models for young women, from the beginnings of Christianity with St. Helena, the mother of the Emperor Constantine, Catherine of Alexandria, venerated as scholar and martyr, and St. Cecilia, patroness of music. The Middle Ages is represented by Catherine of Siena, theologian and activist who worked to bring the papacy back to Rome from its exile in France. Teresa of Avila was a sixteenth-century reformer of the Carmelite Order and named a Doctor of the Church. Directly associated with the Sisters of the Sacred Heart are the figures of St. Margaret Mary Alacoque, the seventeenth-century nun granted the vision of Christ's Sacred Heart, and St. Madeleine Sophie Barat, the founder of the Society of the Sacred Heart.

The architect was Charles D. Maginnis (1867-1955), an immigrant from Londonderry, Ireland by way of Toronto. Maginnis' leadership revolutionized the architecture of Roman Catholic institutions in America (Richardson). In 1909, the firm won the competition to design Boston College and in the 1920s would build the library, chapel, and dining hall for the College of the Holy Cross, Worcester. The firm had then become highly honored; Boston College's Devlin Hall had received the J. Harleston Parker Gold Medal in 1925, and the Carmelite Convent in Carmel, California (1925) and Trinity College Chapel in Washington, D.C . (1927) both won the American Institute of Architects' Gold Medal. Maginnis was an admirer of the American Eclectic movement (1880s-1930s) which made use of a variety of historic expressions. The Newton Country Day School Chapel is English fifteenthcentury Gothic. Its style shows an admirably simple practicality, yet evokes warmth through the use of wood for side paneling and roof. In the center, for the students, the seats face the front and the altar. The outer seating, used by the Religious for community prayer, is set in a choir-stall structure, aligned with the sides of the chapel and equipped with seats that fold up when they are not being used. It is remarkable that the chapel windows received one-of-a-kind iconography accompanied by museumquality artistic execution. 


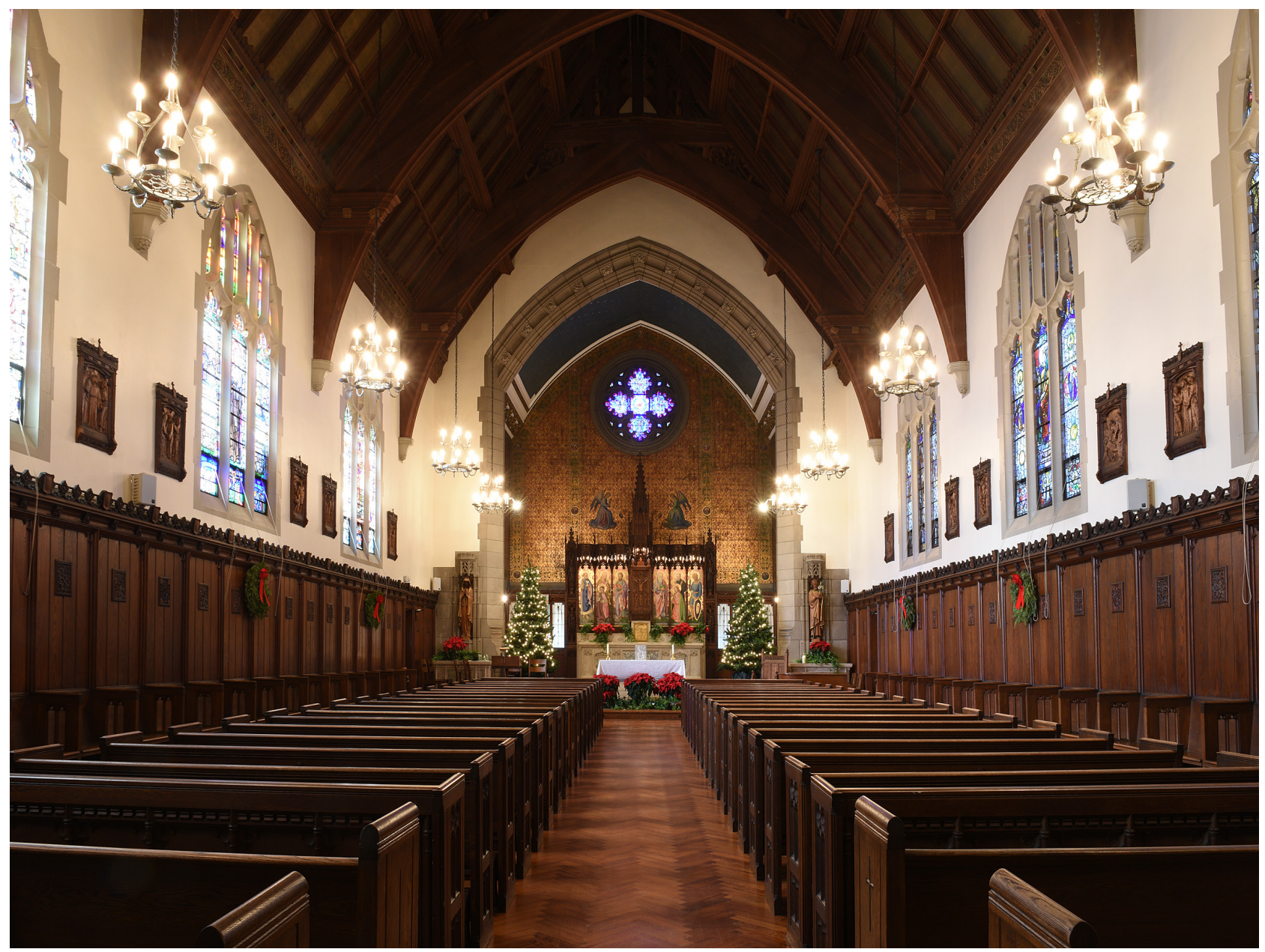

Fig. 1. Chapel, Newton Country Day School of the Sacred Heart, Newton Massachusetts, Maginnis \& Walsh, architects, 1926-1928 
Ireland had witnessed a revival of glass painting that coincided with a resurgence of nationalism in the beginning of the $20^{\text {th }}$ century. In 1901 Edwin Martyn, co-founder of the Irish Literary (later Abbey) Theater, asked Christopher Whall, a pioneer in the English Arts \& Crafts movement, to establish a school in Dublin (Cormack; Bowe, 1988; Bowe 1998; O'Grady). Whall sent over his chief assistant Alfred Ernest Child (Bowe and Cumming, 98-99). In 1903, Child worked with the painter Sarah Purser to establish An Túr Gloine (Tower of Glass). Almost all significant Irish artists in stained glass were at some time associated with the cooperative.

Christopher Whall had made a direct impression on America as well. Whall, as he explained in his book Stained Glass Work of 1905 believed that the studio system must emphasize integrity from design to finish. The artist should "keep his hand of mastery over the whole work personally at all stages" (Whall 268-69). Examples of Whall's work that inspired An Túr Gloine and the Newton Country Day School windows can be found in Boston. The window of Christ in Glory (or the Risen Christ) flanked by Saints Peter and John the Evangelist was installed in 1905 in All Saints, Ashmont, Boston. The window shows Whall's immense freedom in painting. Color, matt, and trace blend harmoniously. Acidetched segments, varying intensities of silver stain yellows and warm and cool hues of vitreous paints create a shimmering field. The artist constantly shifts his paint application to allow light to penetrate in an ever-varying pattern. Christ's mandorla, seemly of flames and clouds, flickers. His ermine collar is depicted in a smooth matt, loosely brushed, and highlighted by thin, irregular streaks lifted off with a stick. Whall's five figures of the Church Fathers were installed in the clerestory of the Church of the Advent, Boston in 1910. Similar to the Irish windows at Newton, they demonstrate a skillful balance of uncolored glass and deeply saturated color. The figure appears as a commanding presence, avoiding illusionistic attempts of spatial recession. (Raguin website)

Seminal Irish stained glass can be viewed in the Honan Chapel, University College, Cork, designed with Celtic inspiration as a core theme (Cormack). A series of Irish saints were executed between 1915 and 1917 by artists of An Túr Gloine, primarily Harry Clarke (1889-1931) and Ernest Child. Child's Risen Christ, 1916, demonstrates the lasting inspiration of Whall's approach to the material of glass, corresponded well with the simplicity of the chapel. Clarke's work is characterized by meticulous craftsmanship and allusion to the continental artists such as the French symbolist Gustave Moreau, the Russian stage designer Leon Bakst, and the English illustrator Aubrey Beardsley (Bowe, 1988; Bowe and Cumming, 100-107). Attenuated, geometrically conceived elements structure the design, even in simple standing figures such as St. Albert, 1916. His often acrid color harmonies intensify the jewel-like appearance of his windows. Clarke also executed a large series of Apostles 
with images of the Stations of the Cross for St. Parick's Purgatory, Lough Derg, Co. Donegal, 19289. His Geneva Window, now Wolfsonian Foundation, Miami, Florida, was commissioned by the Irish Free State in 1926 for the League of Nations in Geneva, Switzerland. Clarke's decision to illustrate 15 contemporary Irish writers, many with explicit sexual imagery, caused the window to be withdrawn.

The Tower of Glass executed a number of commissions expressly for America. The Newton Country Day School is the largest and most sophisticated. The artists include Michael Healy, Alfred Earnest Child, Catherine (Kitty) A. O’Brien, Kathleen Quigley, and Ethel Rhind. Artists kept their own approaches, supported by the encouragement of the collective to favor linear abstraction and an emphasis on planar composition. In Newton Country Day School, each window contains a standing figure in the central light that incorporates deeply saturated colors. The framing lancets are lighter in value; most display several medallions pertaining to the life or the virtues embodied by the saint. The cool abstraction of essential shapes supports a remarkable clarity in the narrative as well as bringing considerable light into the interior. The application of the vitreous paint is visibly acute, never attempting to mimic an illusionistic fall of light on form. Invariably the design is constructed with intense black contours that parallel the size of the lead cames (the flexible links that connect the segments of glass). Thus, the visual graphic of black against intense color becomes a unifying motif. Techniques such as acid etching (the removal of a surface layer of glass of a different color with acid to create a design) also contribute to a jeweled effect.

The windows, in addition to their association with the context of Arts and Crafts contemporary expression, employ conventions from Italian panel painting, manuscript illumination, metalwork, and medieval stained glass. When considering how such works came to have such association with the long history of the production of narrative in religious art, it has been most fruitful to review the context surrounding the founding of An Túr Gloine. Aptly expressed by Jane Maxwell, Principal Curator Manuscripts \& Archives, Research Library, Trinity College, Dublin: "the kinds of people who were involved in the movement which gave rise to such things as Tur Gloine . . . being wealthy, cultured and very often having spent time in training in Europe, will have had reasonably easy access to any publication they desired, by purchase, personal loans among their network of acquaintance, by foreign travel, and by access to the libraries in Dublin and London, including Trinity College Dublin. Trinity, being a copyright library, will have had a copy of all books and journals published in Great Britain and Ireland."

Thus, we turn to "the kinds of people," which for An Túr Gloine meant Sarah Purser, founder and financial supporter for the first twenty-five years of its operation. Indeed, the year before the installation of the Newton Country Day school windows, "An Túr Gloine celebrated its silver jubilee at 
which time the owner has been repaid the last of her seed money" (Bowe and Cumming, 197-198). The enterprise then became legally what it had been in practice, a cooperative with the artists as shareholders. Purser's life shows an extraordinary evolution from artist to patron. She was educated in Switzerland and in 1873, after the failure of her father's business, returned to Ireland, settling in Dublin to study at the Metropolitan School of Art. Like many of her female contemporaries who wished to advance a career, she travelled to Paris to enter Académie Julian, one of the rare Fine Arts institutions to offer acceptance in a special women's atelier. Although she stayed for only six months, she established many personal connections, especially a life long friendship with Louise Catherine Breslau (1856-1925), who became a highly successful painter, achieving the distinction of the Legion of Honor. In Dublin at the end of 1879, she set up her own studio. She became well recognized, exhibiting at the Royal Hibernian Academy of Arts, the Royal Dublin Society, and the Irish Fine Arts Society as well as Royal Academy and Grosvenor Gallery in London. Purser achieved considerable financial success in the next twenty years through her portraits for the Irish and British aristocracy. The fortune that she earned, however, she increased with shrewd investments, particularly with stock in Guinness when it became public company. Members of Purser's extended family had been in the brewing business.

Purser enjoyed a long and active life, and for the next forty years she was a catalyst for the development of arts in Ireland through her interests in education, museums, and galleries. Chief among them was her support for the Hugh Lane Municipal Gallery. Lane was inspired by an exhibition organized by Purser in 1901 of paintings by Nathaniel Hone and John Butler Yeats. Irish-born, Lane had become a highly successful London art dealer and in 1908 began what would become one of the first public galleries of modern art in the world. The process was drawn out, complicated by Lane's early death in 1915. In 1923, the opening of the present museum was expedited by Purser's advocacy that the collection be housed in the mid-eighteenth century neo-classical mansion known as Charlemont House. During the same year Purser became the first female member of the Royal Hibernian Academy and a year later, 1924, she founded the Friends of the National Collections of Ireland. Purser's influence was facilitated by her weekly social gatherings for Dublin's intelligentsia. They took place in the comfortable Georgian Mansion, Mespil House, where she lived from 1911. In 1934, at the age of eighty-six, she organized a campaign to endow an annual scholarship for the history of European painting through Trinity College and the University College of Dublin. The course was taught by the eminent art historian Françoise Henry, who had frequented Mespil House since 1927.

In the literature surrounding the Arts and Crafts revival, we find a notable reluctance to speak of inspiration for the past. The innovators saw themselves totally opposed to previous practices where 
a window was constructed through a division "among a number of nameless employees . . a always resulting in . . . tiresome and dead uniformity devoid of all personality" (Purser, quoted in O'Grady, 101). Purser was keenly aware of stock images from the Renaissance, or more commonly German nineteenth-century religious painters supplying compositions. Replications, for example, the Boy Jesus Disputing with the Doctors (Heinrich Hofmann, German, 1824-1911), the Good Shepherd (Bernhard Plockhorst, German, 1825-1907), or The Light of the World of 1856 also known as Christ Knocking at the Door (William Holman-Hunt, English, 1827-1910), crowd religious edifices as well as illustrated literature of this time. Raphael's painting St. Michael Conquering Satan, 1518, Paris, Louvre, is the basis for the chancel window of 1893 in St. Michael's Episcopal Church, Charleston, South Carolina. Built 1752 - 6, the church has long been considered one of the most elegant buildings of the American Colonies. Tiffany exhibited the window in New York during the summer of 1893 (Raguin 27-31)

Thus Purser, following Whall, issued the clarion call that "each window should be in all its parts the work of one individual artist, the glass chosen and painted by the same mind and hand that made the design and drew the cartoon; in fact, a bit of stained glass should be a work of free art as much as any other painting or picture." (Purser, Anniversary Booklet, p. 9, quoted in O'Grady, 101 and Raguin, 250). However, if Purser viewed the artists in the cooperative as her equals in creativity and dedication, she arguably treated them with the same generosity she displayed toward other artists and organizers of the arts that she knew; she must have shared. Purser was acquainted with European museums and sites through her many periods of travel on the Continent. Some of these trips were deliberate efforts to survey historic and modern stained glass, such as travels in Germany and France with her cousin Alice Barrow. At other times Alice made watercolor sketches of works she saw for her cousin's benefit. Early in Purser's career she spent summers in Paris and Versailles. In 1902, just before the opening of An Túr Gloine she spent three month in the Middle East, receiving mail in Smyrna, now known as Izmir, Turkey. In 1907 she travelled to Palermo, Sicily to view the mosaics. (O'Grady 98).

This was a time when sophisticated taste gravitated toward the sober, but colorful clarity of the early and High Renaissance in Italy. Prominent were clear outlines and sharp contrast between figure and ground, often using gold or monochrome backgrounds. In the trecento and quattrocento, realistic perspective was not yet developed, and even in the High Renaissance perspective simply enhanced the narrative. We can turn to one of the most popular surveys of the day written by the French archeologist Salomon Reinach. His lectures on art and architecture from cave painting through the nineteenth century were published as Apollo: histoire générale des arts plastiques professée en 1902-1903 à l'École du Louvre. The publication was almost immediately translated into most 
European languages; in New York, Apollo: An Illustrated Manual of the History of Art throughout the Ages appeared in 1904. Reinach expressed distaste for overly emotional art of the Baroque, "It is certain that Italian art of the seventeenth century aims at effect, that it dwells unduly on ecstasy and rapture, sentimental effusions, the physical tortures of the martyrs" (Reinach 246). His bias for the early Renaissance, I would argue, resonated with the artists of the Arts and Crafts revival. Reinach illustrated what have now become the canonical works of Duccio (a narrative panel from the Maesta), Fra Angelico, Ghirlandaio, Botticelli, Filippo Lippi, Piero della Francesca, and Giovanni Bellini. Artists were keenly aware of these examples. Melozzo da Forli's fresco of an angel playing a lute was illustrated in Apollo. Part of the Vatican libraries, the painting was a widely distributed image in the nineteenth century. Around 1900 John La Farge used it as the basis of a window of opalescent glass for Judson Memorial Church, Washington Square, New York City. Previously, in 1894, the Tyrolese Art Glass Company, Innsbruck, Austria, used it for a musical angel in a series of windows for St. Joseph's Cathedral, Manchester, New Hampshire.

It is possible that our artists were aware of controversies in the art world and major acquisitions, such as the purchase of the Stavelot Triptych by J. Pierpont Morgan in 1910. The thirteenth-century reliquary of the True Cross, with its narratives of the Legend of Helena and Constantine had survived the French Revolution ultimately to be on loan to the British museum. The triptych, now one of the major treasures in the Morgan Library and Museum, New York is in triptych form, like the window. The center contained the reliquary and each of the side wings three circular enamel medallions. Thus the composition is quite close to that of the Newton windows, especially the window of St. Helena. Archaeologia, the major publication of the Society of Antiquaries of London (now Antiquaries Journal) had carried an article by Sir Charles Hercules Read, Keeper of British and Medieval Antiquities at the British Museum, in an effort to bring attention to the impressive work and keep it in England (Read; Morgan Library). The iconography is highly erudite. We are not confronting stock imagery such as that found in standard cycles of the Life of the Virgin or Life of Christ. The selection of forms is equally creative, and deeply considered for its resonance with historical precedent. A brief overview allows the reader to discover the richness of sources for these innovative artists. 


\section{The Windows:}

Cecilia by Alfred E. Child [Fig.2]

Cecilia, one of the most revered saints of Roman antiquity, is believed to have come from an aristocratic family. Although she became a Christian and had sworn herself to chastity, her parents arranged a marriage to Valerian, a Roman nobleman. After their marriage, her husband was moved by Cecilia's religious passion and converted. Both Cecilia and Valerian were reputed to have been martyred in the third century. According to legend (Golden Legend, November 22), St Cecilia long considered the patron of ecclesiastic music, during her wedding to Valerian "when the organs rang out she sang in her heart to God alone."

The saint is clothed in an ermine-trimmed damask cloak, pointing to her nobility of birth. Curved contours with depth and texture create an effect of natural drapery that is pleasing and elegant. Exuberant, life-like patterns of leaves and roses sprout from intertwined twigs in the border. Flanking Cecilia are four angels, each with a different instrument. To her right one plays the lute, another plays the trumpet; to her left angels play the cymbals and sing. These images are evoked in the Bible: "And David and all Israel played before God with all their might with songs, harps, tambourines, cymbals, and trumpets." (1 Chronicles 13:8). "It is good to give thanks to the LORD [...] To declare Your loving kindness in the morning and your faithfulness by night, with the ten-stringed lute and with the harp, with resounding music upon the lyre." (Psalm 92:14) Child added texture to the window in the treatment of the background surrounding the angels. Pale color tones in the glass complement the rich reds, pinks, greens, and blues of the angels' bright wings and clothing. On the tunic of the angel with the lyre, flashed and acid-etched blue glass brings the design of stars to life, evoking the star-strewn kingdom of God. Our modern sensibilities respond to the selection of lute, trumpet, cymbals, and voice; they stand for the familiar sections of strings, brass, percussion, and voice of an orchestra and choir. Thus, this artist connects the legacy of St. Cecilia with today to bring this composition to life. 


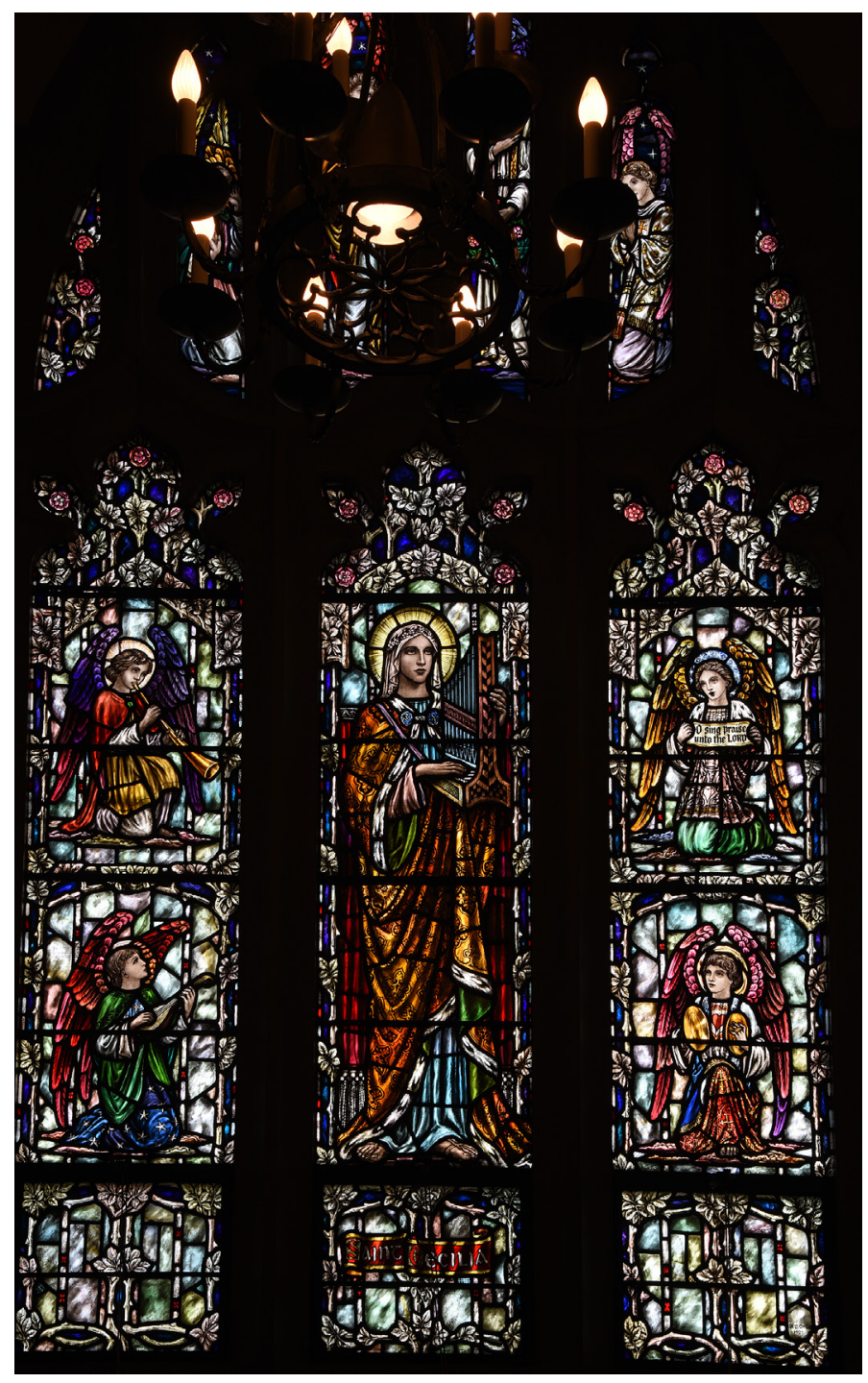

Fig. 2. St. Cecilia, Alfred E. Child, An Túr Gloine, Dublin, 1928-1929. 
Catherine of Alexandria: by Ethel Rhind [Fig. 3]

Catherine holds a book pointing to her being "well instructed in the liberal disciplines." (Butler, Lives of the Saints). Tradition places her martyrdom in the early fourth century under the rule of Maximinus II, emperor of the Eastern Half of the Roman Empire. Although an Egyptian princess, St. Catherine devoted herself to piety and good works despite polytheistic opposition. She angered authorities by denouncing the persecution of Christians. In frustration, the Emperor summoned a group of philosophers to engage her in debate. St. Catherine's eloquence, however, ultimately converted the learned men. He then jailed the saint, but during her imprisonment, the Empress visited and was converted. Catherine was then sentenced to execution on a spiked wheel, but angels intervened to destroy it. Finally she was beheaded. Legends recount that angels took her body to Mount Sinai, the future site of an influential monastery, an image at the top of the window.

Rhind portrays the saint in brilliant color (for additional work by Rhind see Bowe and Cumming 178-180). Acid etching brings forth intricate designs in oranges, reds, and gold on Catherine's rich red fabric. Dramatic drapery pours down her figure in shades of blues and greens like flowing water, elegantly contouring the curves of her body. St. Catherine sits tall upon her throne with Egyptian motifs, with a book in one hand (alluding to her love of philosophy), and a martyr's palm leaf in the other. She holds a wheel, evoking the story of her rescue by angels who broke her torture device. Above her head is an image of Mount Sinai, site of her tomb. The image below shows St. Catherine converting the pagan philosophers [Fig.4]. We feel a tangible polarization as the saint is engaged in lively debate with the men on either side of her. Clothed in soft yellow with a bright glowing halo around her head, she is portrayed as a ray of knowledge. 


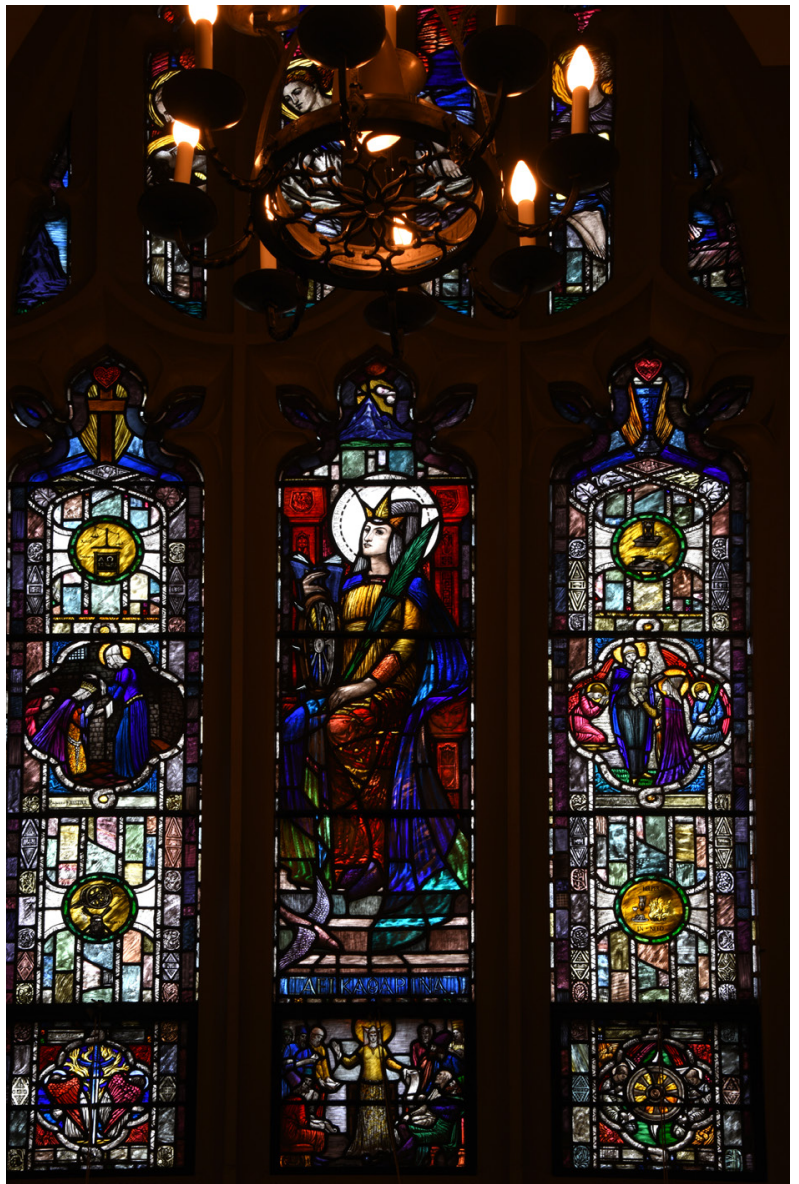

Fig. 3. St. Catherine of Alexandria, Ethel Rhind, An Túr Gloine, Dublin, 1928-1929.

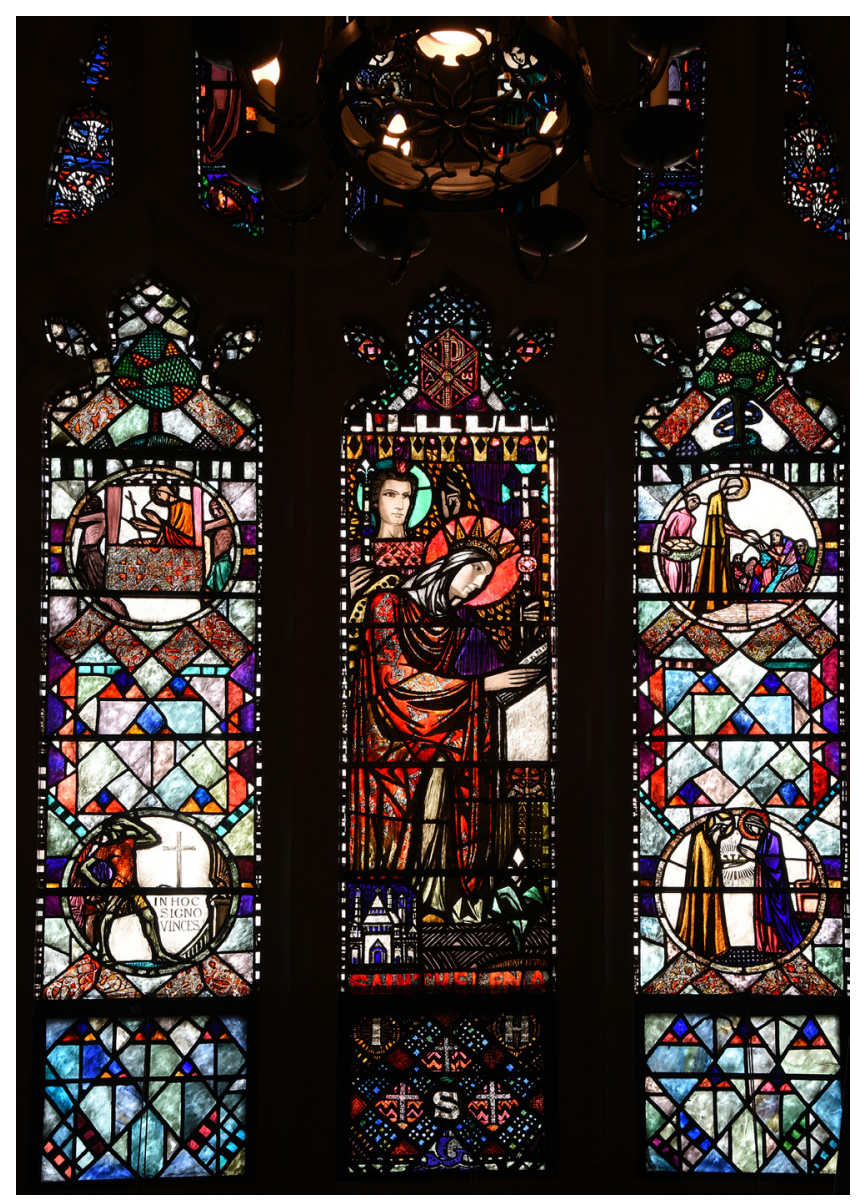

Fig. 4. St. Catherine of Alexandria, detail of Catherine amid the Philosophers. 
Helena by Michael Healy [Fig.5]

Helena was the mother of Constantine the Great whose enactment of the Edict of Milan in 313 formally established Christianity as a tolerated religion in the Roman Empire. She was deeply honored by her son, who named her Empress. Eusebius, bishop of Caesarea (d. $339 \mathrm{CE}$ ) records that in 326-28 Helena undertook a voyage to Palestine where she built a church at Bethlehem and on the Mount of Olives where Christ ascended (Eusebius, Book III, 24-43). Tradition from the later fourth century credits her with the discovery of the cross on which Jesus was crucified. She and Constantine are credited with constructing the Church of the Holy Sepulchre in Jerusalem honoring both the site of Christ's entombment and this sacred relic. The Golden Legend, compiled in the thirteenth century, relates many legends but all agree that Helena discovered the True Cross (Golden Legend, May 3). A scene in the window shows Constantine seeing a cross and includes the inscription in Latin "In this sign, you will conquer."

As Empress of the Roman Empire, Helena is pictured in royal magnificence. Acid etching on her cloak conveys the delicate intricacy of lace; crimson robes envelope her stately figure. Healey constructs the image as if it were cloisonné enamel, evoking the metalwork popular in the Middle Ages. The jeweled cross evokes precedents such as the Cross of Cong which had been made to enshrine a relic of the True Cross, acquired in 1122 CE by Turlough O'Conor, High King of Ireland (National Museum of Ireland NMI R2833). Replicas of the processional cross were made by the Edmund Johnson Company; one was acquired in 1916 by the Honan Chapel (Kreilkamp, Fig. 30). Starkly contrasted with the lavish robes of the central figure, the top image in the right lancet shows the Empress in muted amber tones feeding the poor [Fig. 6]. Here, it is the people receiving her mercy who are wearing the attractive colors. Abstract silhouetted forms that minimize facial expression focus the viewer's eye on gesture. These compositional devices recall the liturgical textiles that were being produced by the Dun Emer Guild in the early twentieth century. Katherine McCormack produced an altar frontal for Honan Chapel in 1916 (Kreilkamp, Fig. 44) and Jack Butler Yeats a series of Sodality banners in 1904 for St. Brendan's Cathedral, Clonfoert (Kreilkamp, Figs. 121-124). 


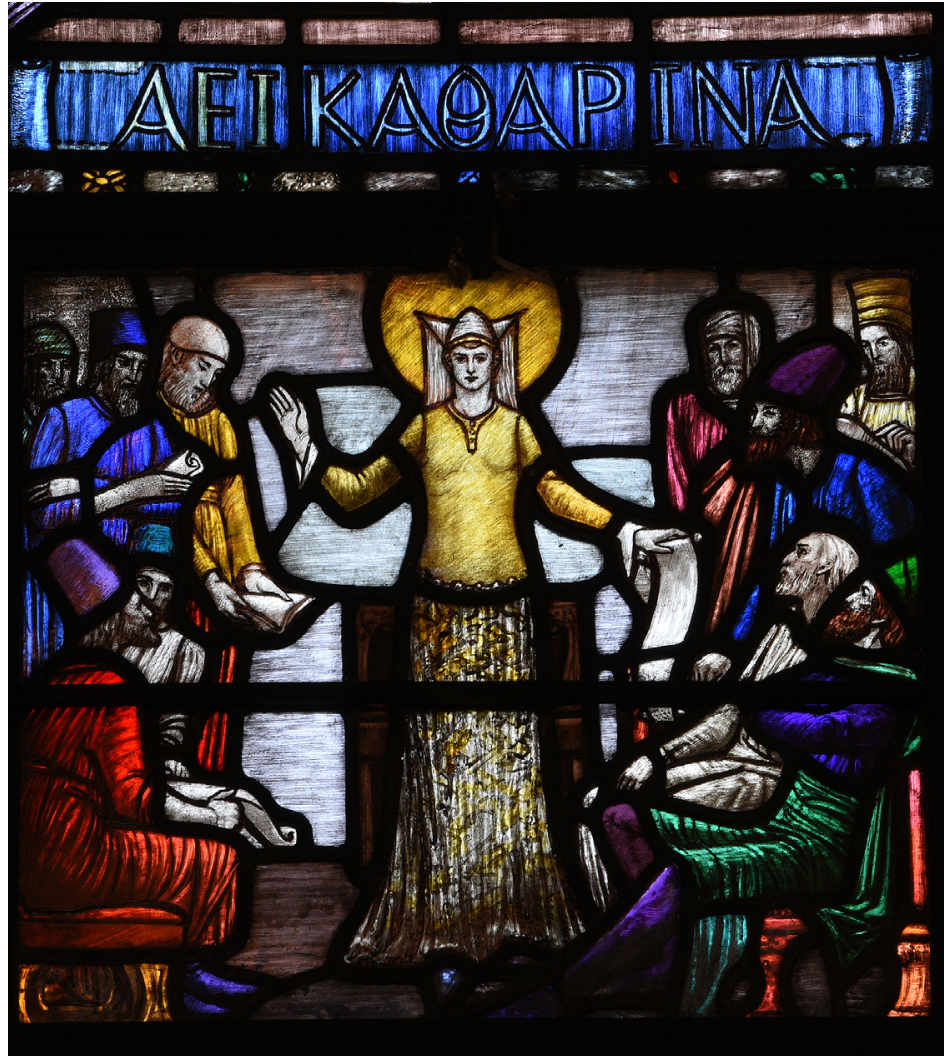

Fig. 5. St. Helena by Michael Healy, An Túr Gloine, Dublin, 1928-1929.

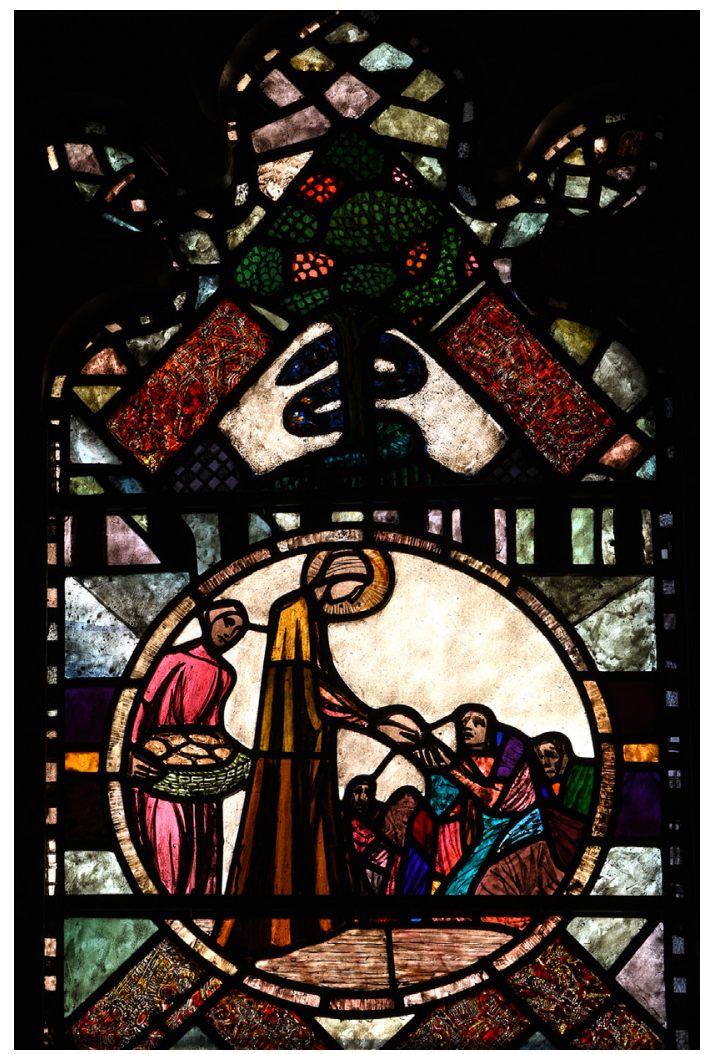

Fig. 6. St. Helena by Michael Healy, detail of Helena distributing alms to the poor. 


\section{Catherine of Siena by Catherine O'Brien [Fig. 7]}

Catherine (1347-1380) defied her parents' effort to arrange her marriage. Eventually she was allowed to join the Third Order of the Dominicans. Third Orders were ways that laypersons could engage in religious practices without formally committing to a religious life. In addition to good works among the poor, Catherine engaged in correspondence with civil and religious leaders to mediate Italian civil strife and return the papacy to Rome.

Catherine O'Brien depicts the saint holding a large red cross, evoking her veneration of Christ's suffering. A warm glow of light encapsulates the saint; striated brush strokes pull the viewer's eye into her figure. The deep, rich purple of her robes cascades down to shift to white and gold hues, as white lilies, a symbol of purity, spring from the earth. Below, St. Catherine receives the stigmata. Beams of light extend from Christ's feet, hands, and side and we read her utterance vidi arcana dei (Latin: I have seen the secrets of God). "The Lord [ ... ] stamped on her body the print of His wounds." (Butler, April 30) The lancets on either side show both spiritual and political episodes of her life. On the left, center, Catherine experiences a vision of the founders of various religious orders calling her to them, including St. Francis and St. Dominic. To the center right, the saint is in Avignon, urging Pope Gregory XI to return the papacy to Rome and to reform the church [Fig. 8]. Although the pope and cardinals are the leaders of the church, they sit below the tall and authoritative St. Catherine, their colorful robes contrasting with her white garments. Catherine's outspread arms inject motion horizontally; the eye is carried from the ornate garments of the pope to the deep crimson of the cardinals as her arms rhythmically sweep across the composition. The composition and use of local color in each of the figures are highly reminiscent of the trecento and quattrocento composition of artists such as Duccio or Giovanni de Paolo. Giovanni di Paolo actually painted an altarpiece containing ten predella panels on the life and miracles of the saint in 1447. The panels are now dispersed, some in the Cleveland Museum of Art and in the Metropolitan Museum; it is unknown if these models were available to O'Brien in 1928 (De Fernandez-Gimenez). 


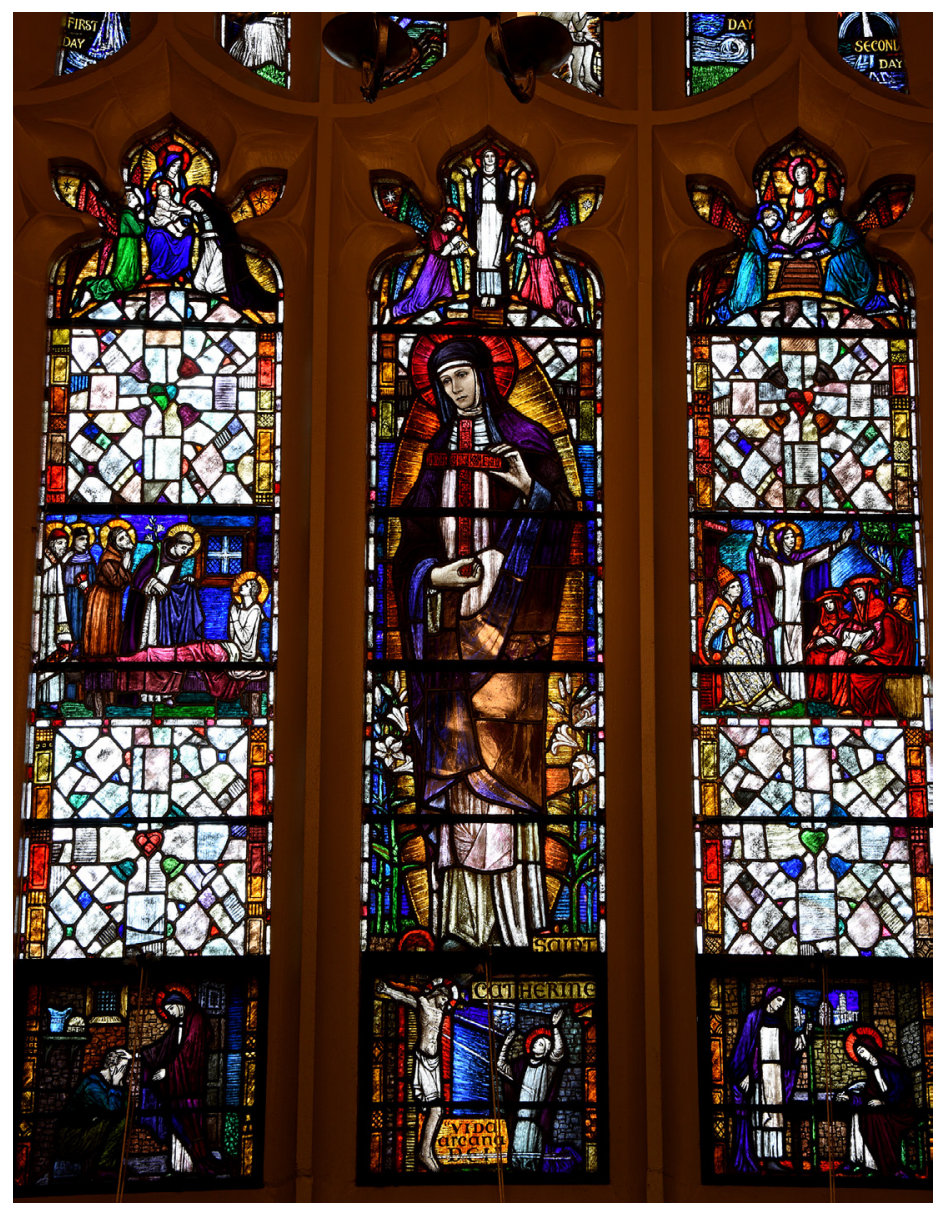

Fig. 7. St. Catherine of Siena by Catherine O'Brien, An Túr Gloine, Dublin, 1928-1929.

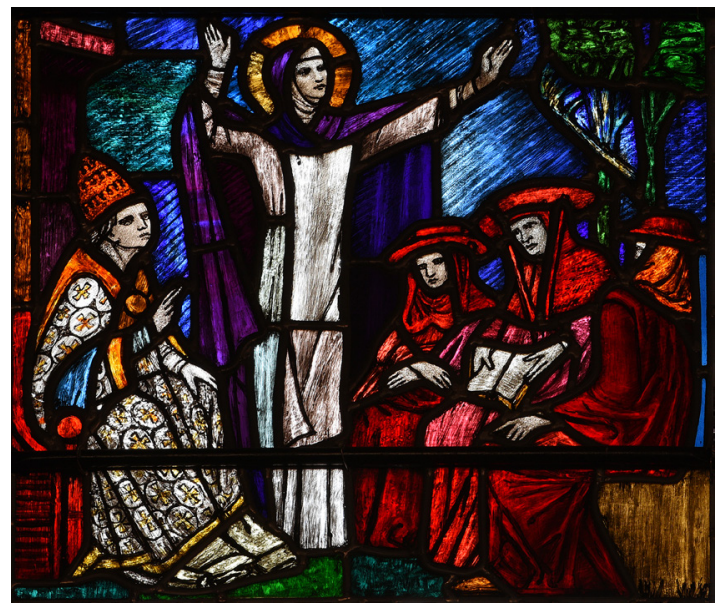

Fig. 8. St. Catherine of Siena, detail of Catherine at Avignon before cardinals and pope. 


\section{Teresa of Avila by Michael Healy [Fig.9]}

Teresa (1515-1582) joined the Carmelite Order in 1535. One year later she experienced significant illness, including partial paralysis. During her healing process, she meditated on Christ's passion and claimed to have various visions of him that cured her. Her campaigns to reform her Order faced opposition but she was ultimately successful and founded the convent of Discalced Carmelite Nuns of the Primitive Rule of Saint Joseph at Avila in 1562. Her influence extended to religious and secular leaders of her time through numerous writings, including The Interior Castle, The Way of Perfection, and her widely read autobiography, The Life of Teresa of Jesus. One of her best known poems states: "Let nothing disturb you. Let nothing make you afraid. All things are passing. God alone never changes." In the window the dove of the Holy Spirit hovering over the saint depicts the saint's writing that "I saw over my head a dove" (Life, Ch XXXVIII:13), an experience that occurred on the Eve of Pentecost, when the Church celebrates the Descent of the Holy Spirit on the Apostles. The miracle of a rescued child is associated with the construction of a new convent in Avila in 1561. Teresa's nephew was crushed by a collapsed wall; Teresa took him in her arms and the child was restored to health. (Canonization Acts 1625).

The saint's drapery is layered in languid curves that gather on her left side; drawing the viewer to the church she holds. The muted blacks, browns, and tans of her clothing evoke the modest religious life of the Carmelite Order that she championed. In the left lancet, at the top, we see the Virgin Mary surrounded by orange and yellow beams of light that pulsate from her figure. Below her is the angel with the fiery dart named in the saint's autobiography: "With this he seemed to pierce my heart several times so that it penetrated to my entrails ... he left me completely afire with a great love for God." (Life, Ch XXIX 16-19) [Fig. 10]. Intense impressionistic brush strokes depict the wild, blazing fire on the arrow's tip. Mosaic-like patterns in the angel suggest that the artist was familiar with Early Christian art. Healy seamlessly integrates the windows' structural lead lines into his painted design, visible in background pattern as well as figure. 


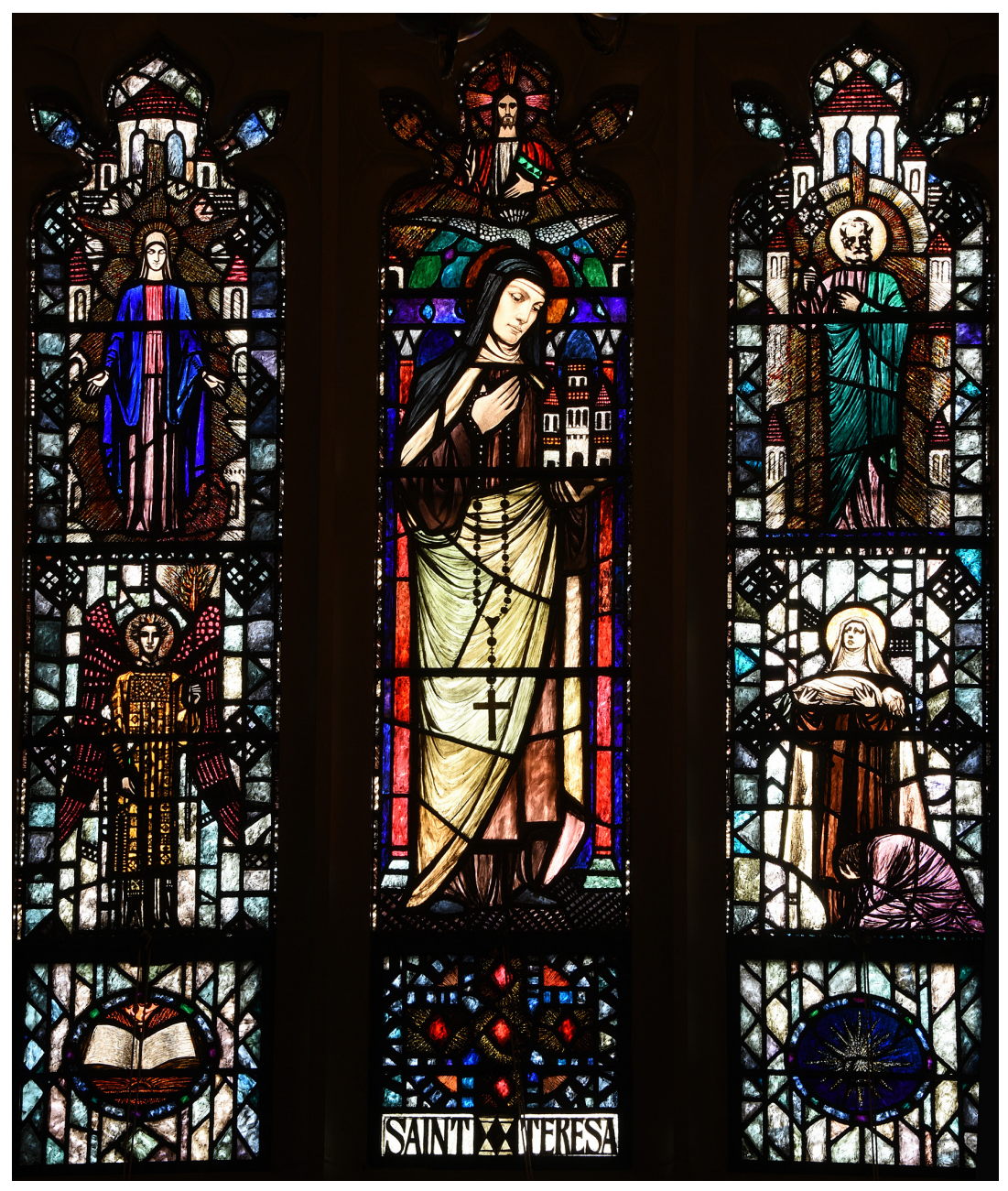

Fig. 9. St. Teresa of Avila by Michael Healey, An Túr Gloine, Dublin, 1928-1929.

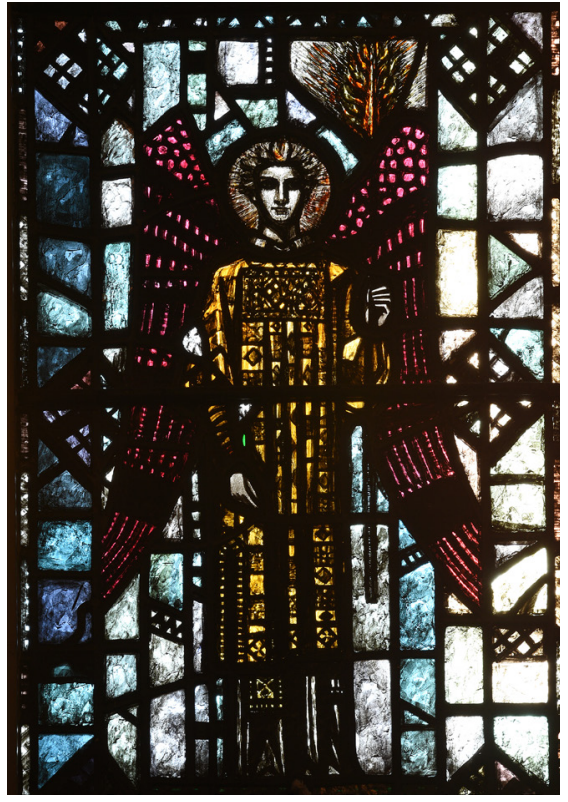

Fig. 10. St. Teresa of Avila, detail of angel with the fiery dart. 
Margaret Mary Alacoque by Hubert McGoldrick [Fig. 11]

Margaret Mary Alacoque (1647-1690) was born in L'Hautecour, France; following her communion at age nine, she was stricken with illness and bedridden for four years. Moved by a religious vision she associated with her healing, she entered into the Visitation convent in Paray in 1671. Once immersed in religious life, Margaret Mary told her superior that she experienced frequent visions in which she conversed with a thorn-crowned Christ. In one specific vision, "He showed this [his love] clearly in a special vision showing His Divine Heart pierced with love for men. He will make their salvation sure, He will not allow anyone consecrated to Him to be lost. He has a great desire to be known, loved and honored by His creatures" (Letter to Fr. Croiset, September 1689). The devotion to the Sacred Heart of Jesus was officially recognized by Pope Clement XIII in 1765.

McGoldrick weaves the structural lead lines into a quilt-like background pattern that entrances the viewer with its texture and clarity. A symphony of color flows seamlessly, from the burning orange in the angels and angelic monks above to the somber blue of Christ's passion below. Gabriel's Annunciation to Mary appears on the left and, in parallel, on the right is Jesus' revelation of his sacred heart to Margaret Mary [Fig.12]. The simplicity of the silhouettes and solid color evoke Ottonian manuscript illumination. Celtic manuscripts had been a vital part of the discourse in Ireland at the beginning of the century, and Apollo illustrated them, as well as Early Christian mosaics and Byzantine century ivories that offer parallel compositional simplicity. Jesus appears in warm yellows and reds; Margaret Mary is surrounded by cool purples and blues indicative of her humility. The scene is intentionally off balance, with Jesus standing tall. Margaret Mary, however, kneels and looks up at him, her small body occupying less space. The space between these two visually communicates the infinite divide between earth and heaven. Below both scenes, Christ on the Cross appears in a horizontal composition. Jesus' outstretched arms extend into a swath of color that draws the eye from the epicenter of the narrative (Jesus on the cross) to the devout on either side of him. The mourners represent Christianity throughout the ages, a king, a soldier, an African man, monks, and many women. 

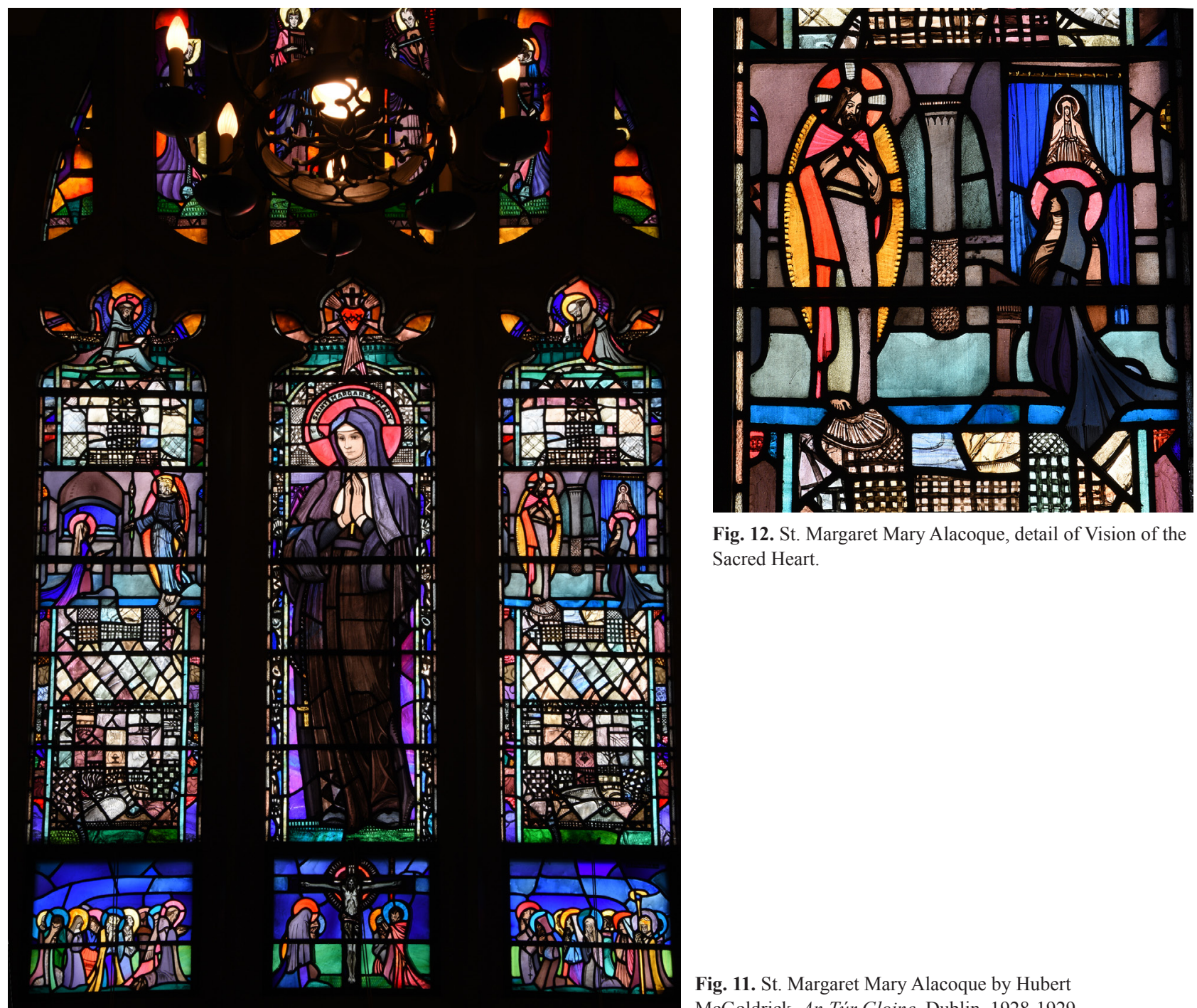

Fig. 12. St. Margaret Mary Alacoque, detail of Vision of the Sacred Heart.

Fig. 11. St. Margaret Mary Alacoque by Hubert McGoldrick, An Túr Gloine, Dublin, 1928-1929. 


\section{Madeleine Sophie Barat by Kathleen Quigley [Fig.13]}

Barat (1779-1865), founder of the Society of the Sacred Heart of Jesus, was born in Joigny, France to a prosperous family. Her brother Louis, eleven years her senior, tutored her in Latin, Greek, Spanish, Italian, history and natural science. Destined for priesthood, Louis also fostered Madeleine Sophie's spiritual development. Religious vocations, however, were difficult after the French Revolution. Finally in 1800, Barat and three companions began a new Order dedicated to teaching inspired by Jesuit models; it experienced rapid growth. The Society of the Sacred Heart of Jesus became formally established in Europe and North America by 1818, and was recognized by Pope Leo XII in 1826. In 1925 Madeleine Sophie Barat was canonized by Pope Pius XI.

Kathleen Quigley based her image on the portraits of the saint, using soft shading to evoke life-like three-dimensionality. Barat had refused to sit for a portrait during her lifetime and therefore there is no official image. Although the School's archives lack correspondence from the School to the Studio (information from the Studio survived) it is highly likely that some imagery was furnished by the Religious of the Sacred Heart. We know through the studio records for Harry Clark that Missionary sisters of the Holy Rosary at Killeshandra sent a holy card image of The Child Jesus appearing to St. Teresa of Avila as a model. A folder relating to windows commissioned for Saint Mary's Dominican Convent, Dun Laoghaire, County, Dublin contains a number of images of female Dominican saints: Catherine of Siena, Rose of Lima, and Agnes of Montepulciano (archives Marta BUSTILLO, Library of Trinity College, Dublin).Thus we can be reasonably certain that the image of Barat was modeled on a print. Barat's face is one of the more "realistic" or conventional elements of the entire program. The child standing before her and the side panels of the window are more abstracted [Fig.14].

The viewer's eye is engaged by pattern from the diamond-shapes in the child's bonnet and gloves to the blush-pink flowers in her billowed dress. The effect is similar to that of The Eve of St Agnes, now Dublin City Gallery, produced by Harry Clarke with the assistance of Kathleen Quigley in 1923. Streaky colors produced by selection of glass and acid etching achieve a similar shimmer of hues. In the hand of the girl is a bright blue book, demonstrating the work of Barat in the education of young women. Above the saint are the Sacred Hearts of Jesus and of Mary, and below her is a picture of houses of her birthplace, Joigny. The side lancets contain four images from the Gospels labeled: Generosity, Courage, Joy, and Humility. On the upper right "Joy" is associated with the appearance of the resurrected Christ to Mary Magdalene [Fig. 15]. The thick vegetation that crawls diagonally across the composition draws the eye from left to right as the somatic tension between Jesus and Mary Magdalene. Jesus' sprawled hands communicate his rejection of her touch. It seems impossible not to remember the gesture of the Magdalene in Giotto's fresco of 1304-06 in the Arena Chapel of Padua, a highly popular stop on European art tours. 

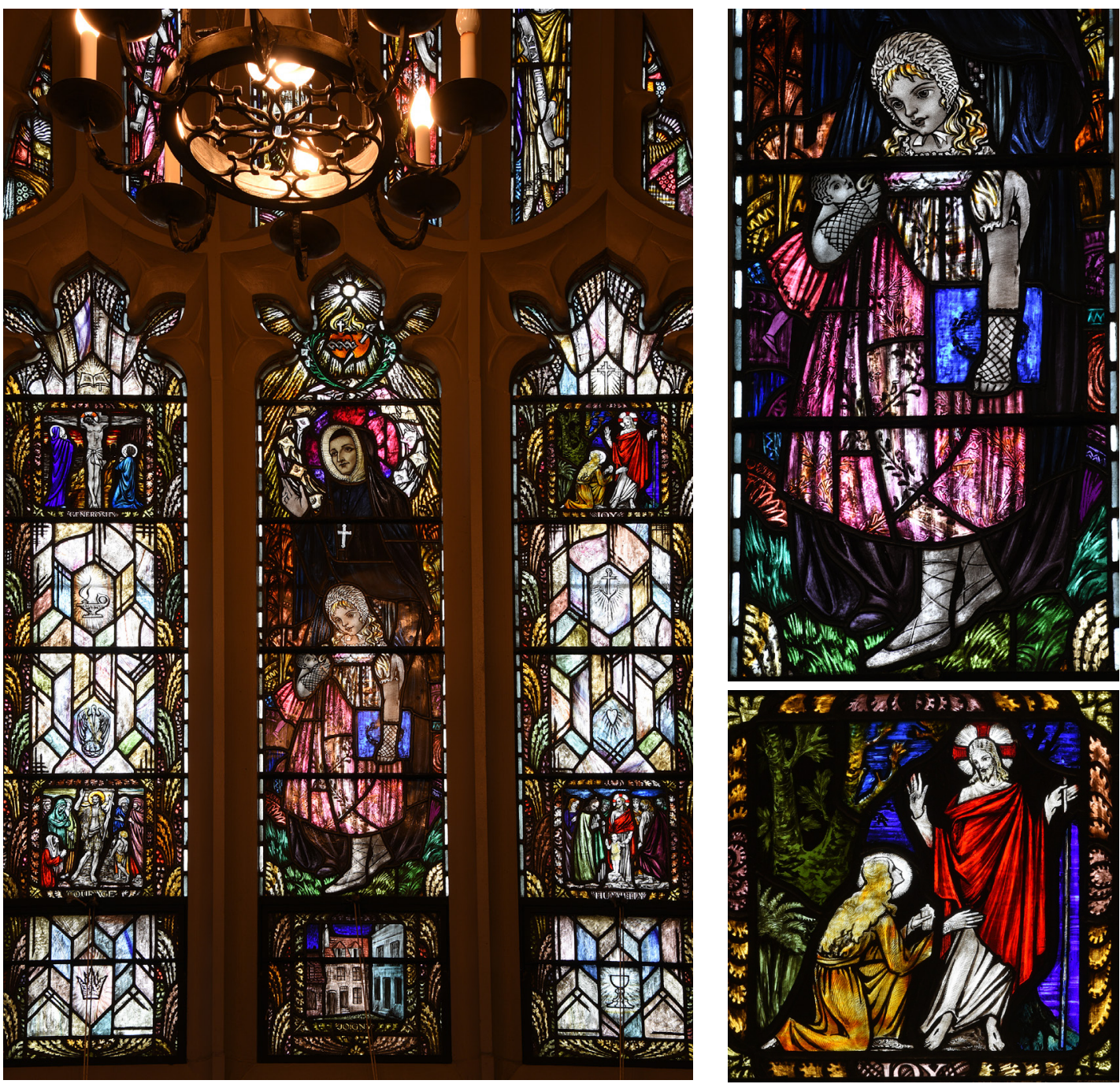

Fig. 14. St.

Madeleine

Sophie

Barat, detail of child.

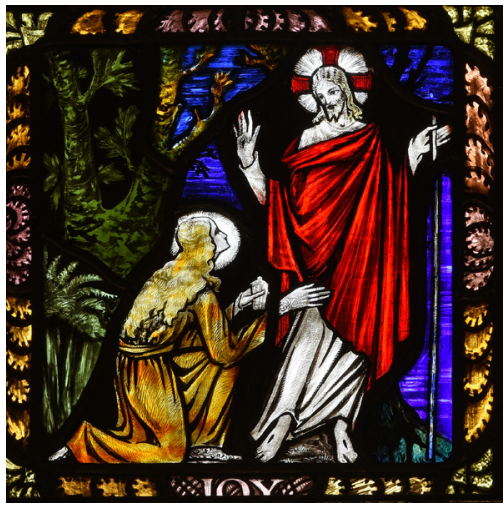

Fig. 15. St. Madeleine Sophie Barat, detail of the Noli me tangere: Mary

Magdalen confronts the Risen Christ.

Fig. 13. St. Madeleine Sophie Barat by Kathleen Quigley, An Túr Gloine, Dublin, 1928-1929. 


\section{Sacred Heart of Jesus and Sacred Heart of Mary by Hubert McGoldrick [Fig.16]}

The rose window above the altar displays the devotion that is at the core of the spiritual life of Religious of the Sacred Heart. Four peripheral medallions and one central medallion form a crosslike structure that radiates from two glowing hearts. The two hearts appear against a yellow radiance surrounded by a victor's wreath of greenery. On the left, that of Jesus wears a crown of thorns. Mary's heart is pierced by a sword, alluding to the prophecy made by Simeon when Mary and Joseph brought the infant to the Temple: "Behold, this Child is appointed for the fall and rise of many in Israel, and for a sign to be opposed - and a sword will pierce even your own soul ..." (Luke 2: 34-36).

A glowing color harmony emerges from the background of this window with stimulating mixtures of azure blue, magenta, and scarlet red. McGoldrick, also the artist of the Margaret Mary Alacoque window, uses this interplay of effervescent hues to unify the composition and engage the eye. Quilt-like patterns throughout the design similar to those from Alacoque add texture. Such detail is transfixing in its intricacy. In each medallion, angels offer a service to God, including music, prayers, and gifts of incense [Fig.17]. The elongated figures of the angels fill the composition and are expressively active. Their drapery falls in abstracted linear patterns, similar to that of medieval manuscripts, injecting motion through repeated flat lines that contour the body. The large, curved wings of the angels sweep around the images to frame them, creating natural and cohesive intersections between medallions. 


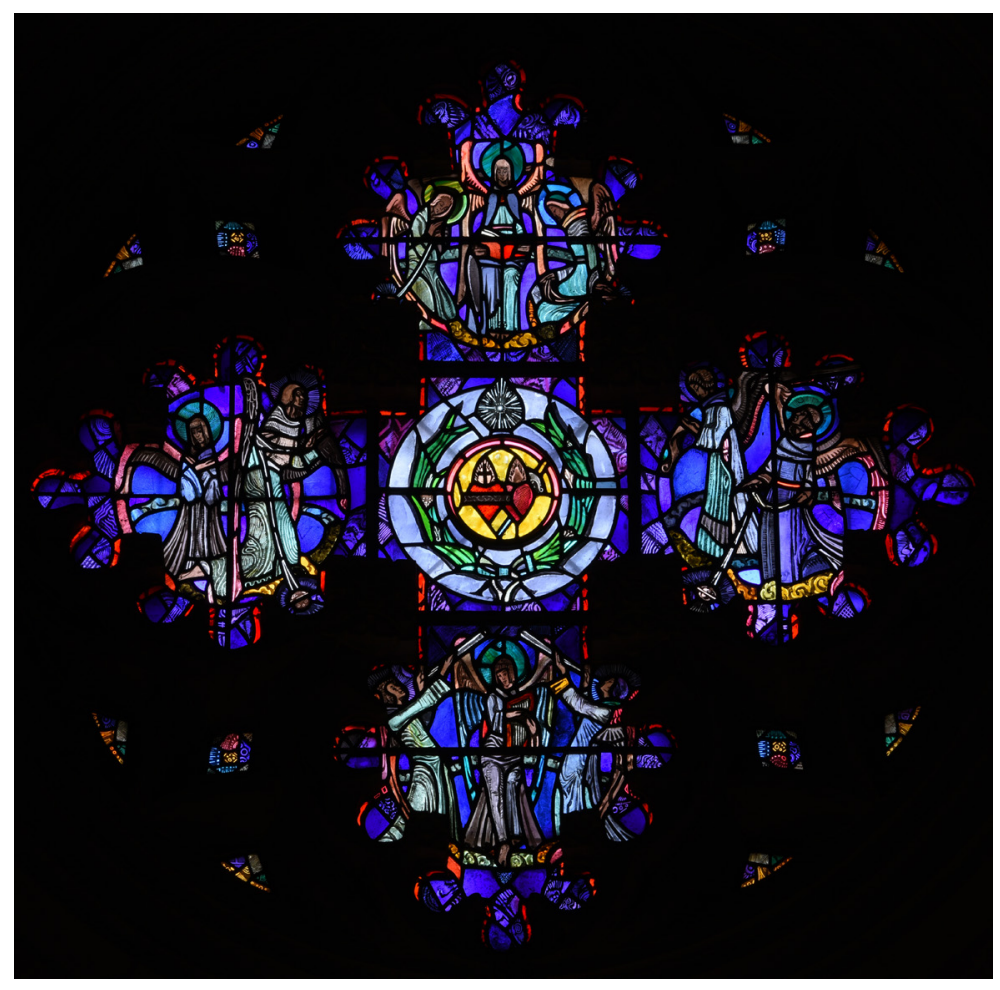

Fig. 16. Sacred Heart of Jesus and Sacred Heart of Mary by Hubert McGoldrick, An Túr Gloine, Dublin, 1928-1929.

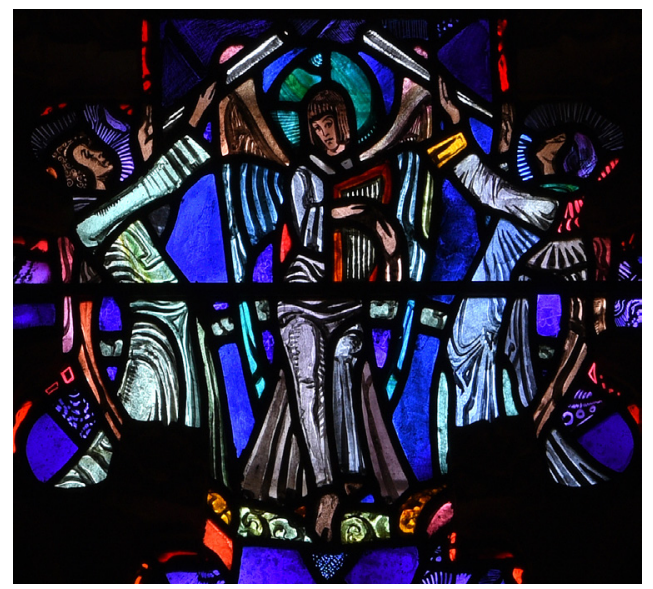

Fig. 17. Sacred Heart of Jesus and Sacred Heart of Mary, detail of angel. 


\section{Works Cited}

\section{Archives:}

The Library of Trinity College Dublin: information provided by Marta BUSTILLO, and Lydia FERGUSON, Librarians, and Jane MAXWELL, Curator of Manuscripts.

Newton Country Day School of the Sacred Heart, information provided by Mary Pat JOY.

\section{In Print:}

An Túr Gloine: List of the Principal Stained Glass Windows to 1929, Dublin n. d. 1919?

CORMACK, Peter. Arts and Crafts Stained Glass. New Haven: Yale University Press, 2015.

BOWE, Nicola Gordon. The Life and Work of Harry Clarke. Dublin: Irish Academic Press, 1989.

BOWE, Nicola Gordon, and Elizabeth CUMMING. The Arts and Crafts Movements in Dublin \& Edinburgh: 1885-1925. Ballsbridge, Dublin: Irish Academic Press, 1998.

BOWE, Nicola Gordon with David CARON and Michael WYNNE. Gazetteer of Irish Stained Glass, Dublin: Irish Academic Press, 1988.

BUTLER, Alban. The Lives of the Fathers, Martyrs, and other Principal Saints, 12 vols. New York: D. \& J. Sadlier, 1846.

DE FERNANDEZ- GIMENEZ, Elizabeth Ourusoff. "Giovanni di Paolo: The Life of St. Catherine of Siena," The Bulletin of the Cleveland Museum of Art, Vol. 54, No. 4 (Apr., 1967), pp. 103-110.

EUSEBIUS. Life of Constantine. intr. trans. by Averil Cameron and Stuart G. Hall. Oxford, UK: Clarendon Press: Oxford, UK ; New York: Oxford University Press, 1999.

GOLDEN LEGEND, of Jacobus of Voragine. trans. and ed. Granger Ryan and Helmut Ripperger, New York: Arno Press, 1969.

KREILKAMP, Vera. ed ... The Arts and Crafts Movement, Making it Irish, exh. cat. McMullen Museum of Art, Boston College, Boston, 2016.

MORGAN LIBRARY. The Stavelot Triptych: Mosan Art and the Legend of the True Cross, New York: Pierpont Morgan Library, 1980.

O'GRADY, John. The Life and Work of Sarah Purser. Blackrock: Four Courts Press, 1996.

RAGUIN, Virginia. Stained Glass from its Origins to the Present, New York: Harry Abrams, 2003, under title The History of Stained Glass, London: Thames and Hudson, 2003.

READ, Charles Hercules. "On a triptych of the Twelfth Century from the Abbey of Stavelot in Belgium, containing portions of the True Cross," Archaeologia 62, 1910: 21-30.

REINACH, Salomon. “Apollo: An Illustrated Manual of the History of Art throughout the Ages." In Orpheus: A General History of Religions. New York: G.P. Putnams Sons, 1909.

RICHARDSON, Milda B. "Chancel Remodeling: Charles D. Maginnis (Maginnis \& Walsh)," The Makers of Trinity Church in the City of Boston, Amherst \& Boston: Massachusetts University Press, 174-194.

WEISBERG, Gabriel P and Jane R. BECKER, eds. Overcoming All Obstacles. The Women of the Académie Julian. The Dahesh Museum of Art, New York, New York and Rutgers University Press: New Brunswick, New Jersey, 1999.

WHALL, Christopher W. Stained Glass Work: A Textbook for Students and Workers in Glass, New York: D. Appleton and Co., 1905. (Repr. 1920, London: Sir Isaac Pitman \& Sons). 
A great deal of the printed and visual references cited are available online:

RAGUIN, Virginia. Style, Status, and Religion: America's Pictorial Windows 1840-1950 http://college.holycross.edu/RaguinStainedGlassInAmerica/Arts\&Crafts/Arts\&Crafts.html http://www.newtoncountryday.org/Chapel

WHALL, Christopher W. Stained Glass Work: A Textbook for Students and Workers in Glass, New York: D. Appleton and Co., 1905. https://archive.org/details/stainedglasswor00whalgoog

REINACH, Salomon. Apollo; An Illustrated Manual of the History of Art throughout the Ages In New York: Charles C. Scribner's Sons, 1904 https://archive.org/details/apolloillustrate00rein The works of art illustrated in Apollo are now accessible online through museum websites. 
64

Interfaces 38 (2016-2017)

LiST OF ILLUSTRATIONS

Fig. 1. Chapel, Newton Country Day School of the Sacred Heart, Newton Massachusetts, Maginnis \& Walsh, architects, 1926-1928

Fig. 2. St. Cecilia, Alfred E. Child, An Túr Gloine, Dublin, 1928-1929.

Fig. 3. St. Catherine of Alexandria, Ethel Rind, An Túr Gloine, Dublin, 1928-1929.

Fig. 4. St. Catherine of Alexandria, detail of Catherine amid the Philosophers.

Fig. 5. St. Helena by Michael Mealy, An Túr Gloine, Dublin, 1928-1929.

Fig. 6. St. Helena by Michael Mealy, detail of Helena distributing alms to the poor.

Fig. 7. St. Catherine of Siena by Catherine O'Brien, An Túr Gloine, Dublin, 1928-1929.

Fig. 8. St. Catherine of Siena, detail of Catherine at Avignon before cardinals and pope.

Fig. 9. St. Teresa of Avila by Michael Healey, An Túr Gloine, Dublin, 1928-1929.

Fig. 10. St. Teresa of Avila, detail of angel with the fiery dart.

Fig. 11. St. Margaret Mary Alacoque by Hubert McGoldrick, An Túr Gloine, Dublin, 1928-1929.

Fig. 12. St. Margaret Mary Alacoque, detail of Vision of the Sacred Heart.

Fig. 13. St. Madeleine Sophie Brat by Kathleen Quigley, An Túr Gloine, Dublin, 1928-1929.

Fig. 14. St. Madeleine Sophie Brat, detail of child.

Fig. 15. St. Madeleine Sophie Brat, detail of the Noli me tangere: Mary Magdalen confronts the Risen Christ.

Fig. 16. Sacred Heart of Jesus and Sacred Heart of Mary by Hubert McGoldrick, An Túr Gloine, Dublin, 1928-1929.

Fig. 17. Sacred Heart of Jesus and Sacred Heart of Mary, detail of angel. 